\title{
MEANING OF PROPOSING DIVORCE IN TUBAN REGENCY OF EAST JAVA (Matrilocal Residence in Proposing Divorce)
}

\author{
Ulin Na`mah \\ (Department of Sharia STAIN Kediri, Jl. Sunan Ampel No. 7 Ngronggo Kediri \\ 64127.E-mail: ulinnakmah@gmail.com)
}

\begin{abstract}
Abstrak:
Keberadaan dan keniscayaan nafkah dalam kehidupan rumah tangga, seringkali dijadikan pusat konflik oleh setiap pasangan suami-isteri. Selain itu, problem nafkah juga dijadikan alasan -baik oleh suami maupun isteri- dalam pengajuan perceraian mereka, baik dalam bentuk cerai gugat ataupun cerai talak. Ini semua tidak lain disebabkan oleh keberadaan nafkah yang ditetapkan sebagai kewajiban laki-laki atau suami. Atribut "pencari nafkah" yang disandang oleh laki-laki seringkali dijadikan alat kuasa kaum laki-laki di atas perempuan. Namun pada situasi tertentu, seperti dalam sistem aturan tempat tinggal setelah menikah yang menganut matrilocal residence, atribut tersebut juga bisa digunakan perempuan sebagai alat kuasa di atas laki-laki, bahkan -lebih dari itu- juga dijadikan alat penindasan perempuan atas laki-laki. Lebih lanjut, kewajiban nafkah di pundak laki-laki merupakan bumerang bagi masing-masing pasangan dan pemicu terjadinya perceraian. Oleh karena itu, menjadi kebutuhan yang mendesak untuk menghilangkan pembakuan peran gender dan lebih mengutamakan kesetaraan dalam pembagian kerja rumah tangga secara kontekstual.
\end{abstract}

\begin{abstract}
:
The availability of nafkah (money given by husband to his wife for household expenses) in family life often becomes a source of conflict. Moreover, nafkah often becomes a reason for husband and wife for divorce. This is due to the obligation for providing nafkah is relied on husband (man) rather than wife (woman). Yet, on the one hand, "nafkah relied on husband" is often used by husband to powerfully control over his wife. On the other hand, in a culture of matrilocal residence (in wife's home with her parents), "nafkah relied on husband" can be also used by wife to powerfully control her husband and this becomes a means for woman to subordinate and oppress her husband. Furthemore, for both husband or wife, "nafkah relied on
\end{abstract}

al-1hkâm Vol.10 No.2 Desember 2015

DOI: http:/ /dx.doi.org/10.19105/ihkam.v10i2.715 
husband" may often becomes a trigger to divorce. Therefore, it is important to redefine such strict division of gender role and contextually give more priority to equality in gender role in households life.

\section{Key Words:}

Proposed Divorce, Nafkah, Conflict, Matrilocal Residence

\section{Introduction}

In 1930 and earlier year, moslem's Indonesian woman thinks that the proposal of divorce from her side is so hard to be granted by the religious court. In another word, religious courts tend to take side on the men's proposal to divorce..$^{1}$ Furthermore, in 1960 th the proposal of divorce to the religious courts from the side of the wife is facilitated and finally legalized in The Law No.1 in 1974 about marriage. But, the religious courts refers to the legal events of courts about divorce which takes "compounded divorce", 2 so it is inconsistent when the process of divorce is ease. Therefore, because many women hurts of unhappy marriage, so the judge of religious court tends to be sympathetic and agreed to the divorce being asked, even if it also happened although the woman was dishonest. In this period, in contrary, religious courts tends to take side of the wife, by making it easy to agree on the proposal of the divorce. ${ }^{3}$

In its development, the divorce in Indonesia today happened on case of husband are divorced by their wife (through the judge decision) or there are more proposal to divorce than being divorced. According to Nasaruddin Umar, it is the impact of globalization, information stream through mass media, one of them is the infotainment show serving actress as guess star -moreover it is a woman- proudly tell about her divorce. ${ }^{4}$ Besides, it is also caused by the woman's independence. This phenomenon is also supported by

\footnotetext{
1 Daniel S. Lev, Peradilan Agama Islam di Indonesia, translation, Trans. Zaini Ahmad Noeh (Jakarta: PT. Intermasa, 1982), 189 and 211.

2Muhammad Amin Suma, Hukum Keluarga Islam di Dunia Islam, (Jakarta: PT. Raja Grafindo Persada, 2004), 160-161.

${ }^{3}$ Lev, Peradilan, 186-189.

${ }^{4}$ Departemen Agama RI, "The divorce rate in Indonesia is in the highest rank compared to another Islamic countries" in Ikhlas Beramal, No. 46, Th. X 2007, 15.
} 
the rate of divorce in few years in the area of religious courts in this country. According to the data taken from the book "Naskah Evaluasi dan Analisa Statistik Perkara MSy.P/ PTA dan Msy/ PA Seluruh Inddonesia Selama Tahun 2001-2005, ${ }^{5}$ shows that if we see it from the kinds of the case the divorce is taken is the case of proposing divorce by the wife for 432.592 cases. While the divorce came from the husband side is 281.151 cases and another case is only 68.053 cases.

But, something surprising happen, in this proposing to divorce era, Tuban religious courts dominate more on the divorce given by the husband. Moreover, the more interesting one is that the reason of the divorce is the economic pressure, which we know that the responsibility of giving the nafkah belongs to the husband.

Besides, in the context of economic pressure, surprisingly it is the husband who proposes the divorce and not from the wife side, which usually comes from the wife side or the wife's reason to propose a divorce. Moreover, in this case the wife who was divorced often absent from the court that can cause verstek (decision without the presence of the defendant). ${ }^{6}$ The absence of the wife without any reason or a legal reason, ${ }^{7}$ although she has been called well, this shows that the wife is willing to be divorced. Although the woman came to the courts, sometimes she is also willing to be divorced by the husband or released her rights to be reduced, and even when she will not get her rights at all, just like mut'ah (husband's giving to amuse the ex-wife) and nafkah 'iddah from the husband.

Does the previous phenomenon, belong to the form of the wife's helpless or the resignation as the second sex in the Patriarchy? How is the relation of the man and woman in this divorce? Because as we know, Javanese is the follower of Patriarchy in the social life, which lead to unfair decision, such as subordination, marginalization,

${ }^{5}$ www.badilag.net/data/Naskah\%20Statistik\%20perkara.pdf. (Cited 15 Agustus 2009)

${ }^{6}$ According to fiqh's experts, "whoever being called to come to the Islamic court and he/ she refused to come, so he/ she belongs to someone who is cruel/zhalim, and it him/ her loose his/her rights".

${ }^{7}$ The meaning of being well-invited to come to the court is the invitation directly given the one who will divorce, if the one cannot be met, the invitation will be given to the head of district or the one in the similar position. See Mukti Arto, Praktek Perkara Perdata pada Pengadilan Agama, (Yogyakarta: Pustaka Pelajar, 1998), 62. 
unfair work division, and stereotype to woman. Furthermore, how is the understanding -through thinking process and empirical phenomenological method- the divorce caused by economyc pressure from the wife's point of view?

\section{The Theory of Conflict in The Husband and Wife's Relation}

The perspective theory that is used to strengthen the analysis of the research is the social conflict. This is so because the divorce problem is social conflict problem which is more prevalent in the world, even in Indonesia. Indonesia is in the highest rank of the divorce rate in a year, compared to Islamic countries in the world. There are two million marriages in a year, but unfortunately the divorce rate adds twice. Every 100 married couple, there are 10 couples who get divorce, and usually they are new couples. ${ }^{8}$

In the year of $2000^{\text {th }}$, it is only $30 \%$ of divorce happened, where the husband divorced the wife, while in the year of 2005 there is 68, $5 \%$ of the divorce proposed by the wife. In the case of divorce, it was found that the number of wives who proposed for divorce is higher. The cause of the divorce is orderly arranged because of unhappy marriage, economic factor, the family crisis, jealousy, polygamy, arranged marriage, underage marriage, and violence in the family life. It is predicted that the reason of high rate of divorce proposal from the wife is because the women think they have the same right as the men, or as the impact of globalization era. ${ }^{9}$

The main character in building the theory of conflict which is more synthetic and integrated is Randall Collins. Sosiological conflict written by Collins is so integrated because it has further micro orientation than macro theory of conflict proposed by Dahrendorf and others. In this case, Collins starts his theory by explaining that the main contribution to the theory of conflict is adding the micro analysis to the macro one. Thus- according to him- giving meaning that makes sociology cannot work well if it is based on micro analysis only. The

${ }^{8}$ Herien Puspitawati, “Teori Konflik Sosial dan Aplikasinya dalam Kehidupan Keluarga" in Bahan Ajar ke-3: Mata Kuliah Pengantar Ilmu Keluarga, available at http://iirc.ipb.ac.id/jspui/bitstream/123456789/40379/2/teori\%20konflik\%20sosial \%20dan\%20aplikasi\%20dalam\%20kehidupan\%20keluarga.pdf. (Cited 10 Oktober 2010), 28.

9Ibid., 28-29. 
theory of conflict cannot do anything without social level analysis. But, while more theory conflict makers believe that social arrangement exist on the outside and force the actors, Collins tends to see the social structure more as the form of interaction than as the impressive external unity. Moreover, when some of the theory conflict makers see that the actor was forced by the external strength, Collins argue that the actor continuously creating social organization. ${ }^{10}$

Collins' effort to approach the conflict from the individual point of view because its root theory stated in phenomenology and etnomethodology. And then the application in the theory of conflict is started by focusing to social stratification system, because social stratification is an institution that relates to many life characteristics, such as the property, politic, carrier, family, clubs, community, and life style. But, the application to social stratification is still in the spirit of phenomenological sociology. According to him, it is very important to base all concepts that are used to analyze daily activities by Phenomenological sociology.

He thinks that social stratification is as the same as all social structures, can be reduced to the individual level in their own daily activities which interacts one another based on the formed way. Furthermore, social stratification idea given by Collins is said to be the theory of conflict stratification.

Another modern theory maker, Lewis A. Coser, also makes a theory on conflict. The theory of conflict is different from Collins, Coser starts his theory of conflict with the view of ideology and politic, which say conflict is positive or tries to unite functionalism and the theory of conflict by considering social conflict function. In contrary, Collins disregard ideological arrangement in the theory of conflict, he prefers conflict as the focus which is based on realistic base, which says that conflict is the central process in the social life. Collins' point of view is based on the scientific commitment to search more causes of social phenomenon, moreover all causes of every form of social behavior. However, those causes have the same focus, that is the theory of conflict with micro and macro characteristics. ${ }^{11}$

\footnotetext{
${ }^{10}$ George Ritzer and Douglas J. Goodman, Teori Sosiologi Modern, Trans. Alimandan, (Jakarta: Kencana Prenada Media Group, 2010), 160-161.

11Nasrullah Nasir, Teori-teori Sosiologi, (Bandung: Widya Padjadjaran, 2009), 21.
} 
Coser admitted that some structural arrangements are the result of agreement and consensus, which show another process, which is social conflict. In discussing all conflict situations, he differentiates the realistic conflict to unrealistic one. Realistic conflict comes from the disappointment to the specific demands happened in the relationship and from the estimation of possible advantage of the participants and those who are appointed to the disappointing objects. The workers who held the strike against management is the example of realistic conflicts, as long as the management indeed has the responsibility of salary increases and some other workers' advantages. Whereas unrealistic conflict does not come from the antagonist rival purpose, but from the need to relieve the stress, at least from one side only. This unrealistic conflict example is in the relationship of groups, the black list is used to draw the condition when someone uses the substitution group as the object suspected by not releasing their prejudice to the opponents group.

Coser said his theory of conflict through the description about hostility in the intimate social relationship, functionality conflict, and conditions which influence conflict with the people outside the group and social group arrangement, as follow: 12

a. Hostility in the intimate social relationship. If the conflict increases in the intimate (micro) social relationships, so the deviation between the realistic conflict and nonrealistic one is harder to be maintained. Because closer the relation is, the bigger the love is, so it will be bigger the tendency to just keep silent than to start the hostility. While in the secondary relationship, just like the relationship with the colleagues, the hostility tends to be showed up. This cannot happen in the primary relationship because the total feeling of the participants on the showing of the feeling might break the relation. The paradox is, the closer the relation is the harder to show the hostility. But the longer the feeling is stressed, the more important to show the feeling in case of maintaining the intimate relations. The effect is when they cannot stand anymore so the conflict will be blewn up and it may be very big.

12Ibid., 21-23. 
b. Functionality conflict. Coser quoted from the research by George Simmel which shows that the conflict might be positive, because it can relieve the stress happened in a group for the unity and balance. Then, coser added that the issue type of conflict subject can decide whether it is a functional conflict or not. The positive functional conflict is when the conflict did not tell about the base of the relation, and the opposite of it the negative functional conflict if the conflict strike one of the values. For example, if someone having the marriage because they wanted to be parents, while the couple does not want to have a child, so conflict about having the child deals with the agreement of the purpose of the relations.

c. Coser said that the conditions that affect conflict with the people outside the group and group arrangements will help to strength structural boundaries. In contrary, conflicts with people outside the group can also increase the integrity of the group. The degree of group consensus before the conflict happened is the most important contextual two sided relationships whether the conflict can increase the group unity or not. But if the base consensus of a group is weak, so the threat from outside can danger the unity. For example, research about the effect of depression to a family has shown that families before the depression period has low internal solidarity will give apathy respon and finally break, while family with high solidarity is proven stronger.

From the two theories of conflict model above, the researcher tried to combine both. We can see from both commitments, that both theories of conflicts can be used to dig the reason of divorce conflict phenomenon because the reason of economic pressure in Tuban, thus, the researcher- obviously- can find the meaning and the truth of divorce phenomenon because the reason of economic pressure in Tuban from the wife's perspective. 


\section{Gender Relation in Javanese}

The researcher also used the concept of the gender relation in Javanese. This was done, because the analysis on the Javanese women's role and status created various conclusions, it is caused by the different point of view and approach in understanding gender relations and the dynamic interaction happen in the gender relation in the society and Javanese culture. Some of the result of the research about Javanese women can be grouped into two different points of view in general. ${ }^{13}$

The first group stated that Javanese women had a high status and power, either in the society or in the family. That position was gained by the women because the existence of bilateral family structure, the general perception said that women and men or husband and wife are creatures who complete each other, and also the women big donation to the family economy which can be gained through their active participation in the production activity. The women important role is also shown in the most Javanese family life that the women who have the responsibility in managing the family income and cost. Besides, the women have the important role in taking decision. This is so different with the status and condition of women in the other developing countries, like Bangladesh, India, and China. Those factors show that women also have a big access to some resources, either in the family and the society. While the power and chances to get the access to the economic, social and cultural resources are the important factor in deciding the women's role and status. ${ }^{14}$

The second group denied that Javanese women had a high status and power. The important role of the women in the economic sector and family management does not always show the women high status and power. Women have double role because they have to look for money for the family and also have to finish most of the domestic work so that they have to divide the time and resources to

\footnotetext{
13Siti Kusujiarti, “Antara Ideologi dan Transkrip Tersembunyi: Dinamika Hubungan Gneder dalam Masyarakat Jawa" in Irwan Abdullah, Sangkan Paran Gender, (Yogyakarta: Pustaka Pelajar, 1997), 82.

14Ibid., 82-85. The weakness of the first group tends to focus on the positive side and some factors which are advantageous to Javanese women to have big role in the family and society, without seeing critically on the mechanism and structure which may stressed on and slowed down women.
} 
fulfill those need at once. Women in general do not have the self control and the control of their activities, mostly women became the target of the hegemonic gender ideology that makes subordination to women. Some of the research result which belong to the second group usually show that there is no significant hitch to Javanese women to actively participated in the process of production, to take part in the economic life management and the decision making in the family, and have the important role and position in the educations..$^{15}$

Both arguments actually have described two sides of coin and those both are completing each other. In one side, it can be seen that Javanese women, the villagers for exact, have the important position in the family and society, but in another side the women do not get the same prestige, chances and power as men. Gender ideology which is hegemonic, having family ideology stressed on women role as mother and wife, adapts and influences the women and men point of view or perception in the daily activities. ${ }^{16}$ In another word, according to White and Hastuti, the women hidden power to the domestic nature structurally has subordinated because it is pressed to the decision makings about ideology to the practical world which is made as public domination by men. However, even in this situation the Javanese women still look for the way to influence the process of decision makings, in the way which actually take the advantage of their feminist. Although formally it does not influence them, but informally the influence is very big. ${ }^{17}$

The same thing stated by Koentjoroningrat that women's role in the income and cost management has made the women and men equivalent. ${ }^{18}$ Geertz also stated that there is Javanese women's domination that is in the domestic matters. However, to Geertz, the effect of domination can be wider to a form of real power. Further, Rogers added that men's domination finally will only stop at

\footnotetext{
15Ibid., while the weakness of the second approach is it is more focus on the existence of structural and cultural mechanism, also hegemonic ideology which gives subordination to women. As the result, this perspective does not see woman as an active creature, who never gives up to the structural and cultural rules.

16Ibid., 84.

17Christiana S. Handayani and Ardhian Novianto, Kuasa Wanita, (Yogyakarta: LKiS, 2004),14-15.

${ }^{18}$ Ibid., 13.
} 
"ideology", which when we face the reality, then it becomes a myth, while the women's domination is a practical real domination which show a more power. This is also supported by Denys Lombard who stated that mothers in Indonesia truly have the most important role. Even, their position is much higher than any other Asian women. Their power, although from the backstage, is still powerful and mainly sourced from their group. ${ }^{19}$

Javanese women's feminist is a big role from women which is supported by practical concept that develop in the Javanese society, just like parents who prefer to live and stay with their daughter than their son, because women are more patient in taking care of things. Moreover, because Javanese women is symbolized as the holder of morality, goodness, sacrifice, patience and responsible values that make them respected more than others.

Talking about the above perspectives, it is actually should be taken back to some facts about Javanese women practical concept. Here, the two perspectives above is completing each other. They are describing two sides of the same coin. This is based on the conclusion that Javanese women are not forbidden to decide a decision taking, as long as it is invisible. Therefore, it cannot be said that Javanese women is oppressed, moreover Javanese women has got something wanted (authority) without doing contradictory to the social culture. The most important is how to make women feels oppressed, hurt, excluded and disregard to their creativity, or women's freedom to express themselves (empowering).

For the family's fund problem can be attached to some various effects of kinship system in the women's wealth, for instance when there was inheritance to woman from a woman, here the woman stayed with their woman's family (a form of matrilocal residence), so the woman's group will take control when they stay with their brothers, and even the women's power will totally lost when they leave their own house or leaving together with their husband's family (patrilocal residence). ${ }^{20}$

\footnotetext{
19Ibid., 14.

${ }^{20}$ Randall Collins, Sociology of Marriage and the Family: Gender, Love, and Property, (Chicago: Nelson-Hall Inc., 1987), 385.
} 
Based on the above residence rules, the rules of legal kinship (matrilineal, patrilineal, brilliant descent) become less important. In another word, whether their children belong to the father or the mother's line, it does not affect the real power of economy. In some patrilineal society in West Africa, women still have their own control to the land to be done and developed into a farm. Thus, the inheritance rules are only as an ideology to cover the real economic situation between genders. ${ }^{21}$

Besides, if it is related to wider society stratification, women did very best in their local community and in the society that does not expand their community. A form of big society tends to have a war network and politics which are dominated by men, and countries which tends to do intervention to bound or escape totally to the local women's power. In the agrarian big culture, women- in the big cities which do not receive a higher level/ class- usually are not appeared and isolated. While women farmers stayed in the suburban have more freedom. $^{22}$

\section{Wife's Understanding on The Divorce}

1. Their resistances to the husband's laziness to work and try hard in getting the family's happiness in the religious and society life.

From the first understanding (resistance to the husband's laziness), actually it has been a discussion in the Islamic Fiqh. In this case, Fiqh decides that the husband's responsibility to give nafkah to family (wife and children) is one of the causes of husband's owning the authority of the leadership in family. As the effect of giving all the responsibility of the family nafkah to the husband, Islam makes the leadership of the family on the husband's shoulder. ${ }^{23}$ As stated by the Allah in the Q.S al-Nisa' 4:34;

21Ibid.

22Ibid.

${ }^{23}$ Fithriyah Wardie Murdani, "Kewajiban dan Hak Suami Isteri dalam Keluarga Islam" Al-Insan, Vol. 2, No. 3 (2006), 19. 


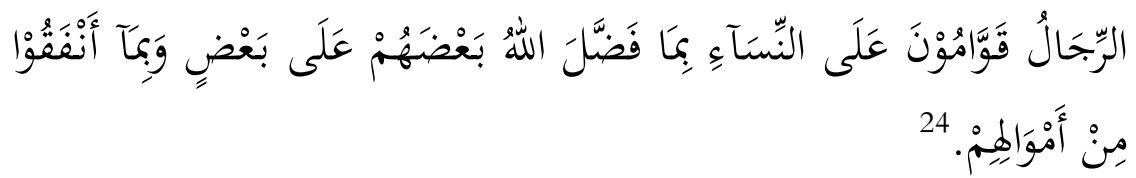

"Men is the leader of women, that is why Allah has added some qualities of them (men) from others (women), and because they (men) have given them some of their treasures."

In the Q.S al-Nisa' 4:34; Allah explains that He has created men with some degree of goodness compared to women, in the form of physical and mental fitrah that made him ready in the family. As the consequences, Allah made husband totally responsible to give nafkah to the family. ${ }^{25}$

Then, the responsibility to give nafkah to the wife either in the hard or easy condition. Although if the economic condition of the wife is wealthy, the husband is still responsible to give her nafkah. This is different with nafkah which is given by the husband to his relatives, which happens only if the husband have extra money, and not in the condition of not having anything. Besides, men have to give nafkah to his relatives only if their economic condition is poor. 26

Further, jumhûr or the majority of ulama gives opinion that the wife can propose fasakh (proposing divorce by the wife) to the judge in the condition of not getting nafkah from the husband, which finally the judge will give the talâq raj' $^{2} .^{27}$ The giving of fasakh rights here is because the husband has hurted or endangered and have no responsibility to his wife. Al-Syâfi î has

${ }^{24}$ Depag RI, Al-Qur'an dan Terjemahnya (Madinah: Mujamma' al-Malik Fahd li Thiba'at al-Mushaf al-Sharif, 1998), 123.

25Murdani, "Kewajiban", 19-20.

26Ibn al-Qayyim al-Jauziyyah, Zâd al-Ma'âd, V(Bairut: Muassasah al-Risalah, 1994), 508.

27Makkiyah Ulama thought that divorce because of the poorness or economic pressure as talaq raj' $\hat{\imath}$, so husbands will only have the rights to return in the 'iddah period in one condition that the husband's economic condition is better. Therefore in this case Malikiyah Ulama have given a solution to the wife who did not get their nafkah from her husband by giving her rights to propose ta 'liq (talaq raj' $\hat{\imath}$ in the wife's request to the judge). See al-Zuhaylî, Al-Fiqh al-Islâmî wa Adillatuh, VII ( Suriya: Dar alFikr, 1989) 513 and Tim, Masyrû' Qanûn al-Ahwâl al-Shakhsiyyah al-Muwahhad li alIqlimain al-Mishr wa al-Suriy, (Beirut: al-Dar al-Shamiyyah, 1996), 189-191. 
also discussed that the husband's uncapability to give nafkah to his wife will make the wife in sorrow, even it can endanger or threaten his life, which is death in hunger, thirsty and naked. ${ }^{28}$ Al- Syâfi î also uses qiyâs awlawtî, that the wife can propose a divorce to his husband through the judge with the reason that the husband cannot give her physical nafkah (impotent), although this reason would never make someone's life in danger. ${ }^{29}$ Therefore, giving the wife rights to propose divorce is because not be given nafkah by the husband is more exact and worthy than because of not be given phisycal nafkah. While Wahbah al-Zuhaylî prefers to choose the opinion of Jumhîr or the majority of ulama (Malikiyah, Syafiiyah and hambaliyah) which explains that one of the giving of fasakh rights is because endangering the wife's life, the same as the statement of hadîts (it is not endangered and harmful in Islam). ${ }^{30}$

Regardless of all differences above, actually the responsibility of giving nafkah mostly become Boomerang or the cause of the conflict in the husband and wife life. And often it becomes the reason of the divorce. So that, the responsibility of the nafkah from the husband is the trigger to divorce when the men cannot fulfill it and the wife asks for it all the time (to make him not lazy to work).

While based on the theory of marriage market, basically someone has already had their own property source such as sexual interest, personality, earnings, other economic assets, prestige and the following culture to be traded in a marriage institution. ${ }^{31}$ In this case, when the husband is considered as the nafkah earner (wage earner) cannot look for it anymore, so in this condition the husband has lost his property to be traded in his family life. Then, the next condition- is based on the concept of

\footnotetext{
${ }^{28}$ al-Syafi 1 i, al-Umm, I, (Bairut: Dar al-Kutub al-'Ilmiyah, 1993), IV:154-155. Even the poor economic condition of the husband can be seen as the husband's nusyuz to the wife.

29Ibid., IV: 155. The absence of physical/ external nafkah in a short time can threat someone's life, while the absence of mental/ internal nafkah in a short or long time will threat someone's life.

30al-Zuhaylî, al-Figh., VII: 513.

${ }^{31}$ Collins, Sociology of Marriage, 11.
} 
role expectation (the hope to the task and or the role), tradisional role expectation ${ }^{32}$ for exact is something that disliked by the wife, which is the condition where the husband cannot work and cannot give any nafkah, then continues to the stressful condition and conflict in the family.

In another word, when someone cannot fulfill or feels reluctant to fulfill his couple's wish, so the wife will think that she is rejected and having the unfair condition. Having rejected, being the second and getting unfair treatment feeling is the biggest potential reason to lid on conflict and divorce, started by the stressful condition of the individual and the rift home's condition, just like in this case- before having the legal divorce, the husband has gone away the house for 2 years as the logical implication of the matrilocal residence tradition that happens in Tuban.

Besides, another fact is the existence of the decreasing family economic factor or even the poverty factor. As we know that economy is a crucial problem in a family, because the marriage institution is a way to fulfill the daily need and the economical unit division. If the marriage can still do its function, so the marriage can be successful although the love is decreased. In contrary, in this case it lost their both marriage function and there is no cooperation between husband and wife to get them back. Therefore, there is no reason anymore for the wife to stay together or to live apart with the husband. In this condition, finally the wife decides to divorce or to end her marriage, for her and their children future. Even it is explained that giving goodness to the husband later in the sayings "badhe nopo-nopo tiang jaler misale badhe nikah malih pun mboten gadah tanggungan" (if the husband wants to do everything for example he wants to

${ }^{32}$ Traditional role expectation demands for a husband to work outside the house, although it is only for doing- cleaning- the backyard, but not doing the housework (domestic work). Moreover he really hopes that his wife responsible for the harmonious family condition in their own big families. In another side, he also hopes that the financial decision will be only taken by him, while the responsibility to the husband-wife sexual relation will become their responsibility (both). 
marry another woman, it can be done because he does not have responsibility to his wife anymore). ${ }^{33}$

Besides, Allah dislikes laziness and it is also decreasing the dignity of the human being. Thus it can be explained that the meaning of "mboten sahe" here is that men who are jobless or reluctant to work belong to immoral men or people who have no dignity. The demands to work hard is not for stacking property, but the most important thing is to have earnings (job), so that naturally the man will get his dignity. As the sayings said الوَقَتُتُ أَتْمَنُ "مِنَ الذَََّبِ (time is more worthy than gold). Further, the condition of the jobless husband or the husband who is reluctant to work has made the wife ashamed, because there is a javanese concept "apiking suami gumantung istri, apiking anak gumantung ibu" (in this context, it indicates the weakness of the wife) and "swarga nunut, neraka katut" (this context has indicated that the wife also feels the miserable life when the husband is jobless or reluctant to work).

Besides, based on the researcher's observation, the women who are strictly asked for divorce or receive herself to be divorced by the husband- although actually the propose of the divorce is started by the description of husband's will to divorce in every quarrel- have the experience of working in the city or outside the city in the past time and or having the experience as a wife who works while she lives with her husband. Some of the job carrier they choose such as the maid, the baby sitter (taking care of children) and the clerk with salary Rp. 400.000 in a month for average.

Based on the above explanation, it can be stated that woman is more ready to work everything even as "pengerok aqua". Thus the economic independence of a woman (wife) is higher than the man (husband), besides that some traditions applied in the Tuban society. Further, finally the economic independence of Tuban's women has given some power for them to be ready to be divorced or asks the husband to divorce, because of specific reason.

\section{Their Husband's Resistant to the Matrilocal Residence Tradition.}

33SM, Interview, Tuban, 27 March 2010. 
Next, to the second understanding, actually comes from the word and ngawulo tradition. Ngawulo means mantu dherek morotuwo (the son/daughter in law lives with the father in law), merdamel kumpul mertuwo (work with or becoming one family with the parents in law), and hasile disukakne isteri trus didamel sakeluarga (the earning is given to his wife to be used in fulfilling the daily needs of the big family). If the woman (wife) is the only child of the family means nggih ngrumat sampek tuwek" (you must take care of the parents in law or ngawulo until they become old) as a form of birr al-wâlidain (worship to parents), and sometimes if the parents in law permitted, ngawulo can be done until you have your own house. ${ }^{34}$

Generally, Tuban's women always think of having the family life in the parents' house or stay with her parents. Totally does not want to stay with the parents in law's house, because if she has to stay with the parents in law, she is worried of being the mocking of the parents in law and neighbour if she cannot fit and follow the parents in law's wish. Thus, staying together in the parents in law's house causes limitation in the daily life. Therefore, it is possible that a woman will voluntary be eager to stay with the parents in law if the husband is the only son of the family or the husband has few relatives or a few kumpulane (family member). In contrary, if the woman or wife does not voluntary want to stay with the parents in law although the husband has few kumpulan, so the wife feels that she does not break the law or breaking the limit. This happened because the man or husband stays with his wife's parents. If this problem continuously happen or there is really oyok-oyokan or disagreement about the place to stay, and the couple stays on their own opinion of supporting their own parents, it can cause divorce. And the divorce caused by the disagreement about the place to stay has happened for a long time ago.

Problems of disagreement about the place to stay can be a conflict, because the relation of husband and wife in the family is described by Engels as relation between capitalist and proletarian class. Then, the assumption built is that the individual tends to

${ }^{34}$ Ayah LK, Interview, Tuban, 13 February 2010. 
fulfill his own need, and conflict always be there in the family life. This can be seen when we see the rules of the places to stay (residence), that when the Tuban's women (after marriage) stay with the family (matrilocal residence), then the wife will have the authority of her own property. In contrary, the woman's authority will be loosen if she leaves her parents house or stay with her husband's family (patrilocal residence).

Based on the above residence theory, it can be said that economic system can decide the authority of a man and woman. While in matrilocal residence applied in Tuban's society is to place woman in a safe position, or to make the woman free from the man's oppression. Therefore, based on the former research by Nur Syam -the more work done by the Tuban's Women is the logical implication in getting the man's authority. Meanwhile, based on the theory of conflict of Collins, the attitude of Tuban's women toward her husband who tends to exploit or to make her husband under her words is done unconsciously. Tuban's women did this exploiting attitude just because they want to get what they think as their best needs.

Actually, to make women as the owner of the authority through the term of having higher workload is unusual thing. Usually the term of having a higher workload is only a term to make the oppression on women. The term of higher workload is only used by man who cannot stand to ngawulo in the parents' in law's house anymore because he needs to work together with the parents in law or wife with the property status in the wife and her family's hand. In this case, the husband will feel that he does not have the authority anymore and finally desperated that is shown by the term "slacker" or reluctant to work together with the parents in law (man's resistance).

Finally, the woman's work will be harder because besides she has to take care of the house such as taking care of the children, she also has to replace her husband to work with her parents. Although it is so and sometimes the woman asks for divorce to the lazy husband, the woman is still happy rather than 
to live with her parents in law or the husband's family. ${ }^{35}$ This is because the woman has done the best (freely and happily) in their local community based on the wider society stratification side and in the society which does not widen its community. The form of big society tends to have political and war network which is dominated by men, and countries that do intervention to totally limit or erase the authority of local women. In the agrarian culture, women in the big city who cannot receive the higher class, usually invisible or isolated. While women farmers who live in the suburban have more freedom or what we called "Javanese women authority". And these Javanese women's authority exists because there is a concept of "sepi ing pamrih, rame ing gawe", "cancut tali wanda" and "menang tanpa ngasorake".

Tuban's women has proposed her husband who is lazy to work, because they still have a point of view that a husband is someone who lead, be responsible and the wage earner (nafkah earner). In another word, in the woman's point of view, the woman wants to make her husband under her words. In contrary, a man also has a point of view that he is the one who has the responsibility of the family that must have power, but they have to obey the matrilocal residence rules, so they experience the unfinished conflict that makes they are resistant as men. Besides, it can also cause divorce, when the man wants to take the woman to his parents' house and the wife rejects it, or when the man is reluctant to do what the wife said, as to make her husband eager to work. Therefore, each side (husband and wife) -took Collins' principle- who based everything on each material source.

While another form of men's resistance is his decision to work outside town. Therefore, the effort to deny the matrilocal residence becomes higher. This can be described through the

\footnotetext{
35The above meaning can be seen from one of the women's understandings of ngawulo concept, which is "Morotuwo tangi isuk, mantu yo kudu melu tangi. Nek ra tangi bakal digunem morotuwo karo tonggo" (parents in law wake up early in the morning, the son/ daughter in law wake up ealy too. If it does not so, the parents in law and the neighbours will talk about them behind their shoulder). Therefore the women will stay with their own parents after the marriage. Beside that, actually the purpose of the parents to be dikawulani is because their perspective of old ages is "kebo nusu gudel" (parents will go with and need their children).
} 
statements from a widow that "living with a parent in law is hurting. When a husband thinks that the need is fulfilled, they often do not want to be dikawulani (followed or depended on) by the parents in law. 36

Further, it can be explained that in Tuban society- in the context of applied matrilocal residence rules- has happened things that has explained by Rogers, that men's domination finally will stop at "ideology", when it faces reality so it becomes a myth, while women's domination is a practical real domination which shows a life authority. In this case, Tuban's women relate their authority to other women or other people who have relation with them, so this network is so strong and the women's domination becomes a real authority.

Here we can get explanation that the Tuban's women do not think that the higher workload of women than men in the Tuban society belong to the unfair gender. Even, she receives it to strength her authority. From one side, the man (husband) becomes frusteted and reluctant to work because his wife forced him to still be the one who responsible for the wage earner, although he (husband) cannot get it by himself. Further, when the husband does not want to apply matrilocal residence rules or being frustrated and lazy to work, so there will be a long life conflict, which finally leads to divorce.

\section{The Wife's Resistance to the Husband's Wish.}

The last, for the third understanding, which is the wife's resistance to their husband polygamy's wish, actually it also happens in other cities. Today, polygamy- though the unhealthy polygamy- has been mentioned as one of the causes of divorce in the religious courts. Meanwhile, based on the data taken by LBHAPIK, mentioned that the facts happened in polygamy has shown that there are many sufferings experienced by the family, either by the first or the second wife and also their children. From 58 polygamy cases accompanied by LBH-APIK from 2001 to July 2003 shown some form of sufferings to the wife and their children, it can be mental pressure, physical violence, wife and

36MW, Interview, Tuban, 21 February 2010. 
children's abandonment, threats and terror, and also ignorant of wife's sexual right. Meanwhile, there are many polygamy's done without any clear reasons (35 cases). From the existing news, polygamy supports the high rate of divorce proposed by the wife (divorce from the wife). ${ }^{37}$

From the research it cannot be seen that unhealthy polygamy as the causes of divorce or proposing divorce, otherwise the facts show that the husband's wish to do polygamy has leaded to divorce. Further, although there has been Tuban's women resistance to the their husband's polygamy's wish, but on the other side, there must be the woman who fells the sufferings, and on the other side, the husband is in the beneficial position. As we know that woman is the God's creature who is more ready for the suffering (masochistic), and knowing this characteristic, made the husband took it as granted to oppress them. Therefore, in this step Tuban's woman is still the stage of psychological resistance, and therefore it is still woman who is suffering from it, in contrast to make them free from the sufferings so they need to do a law resistance or having the legal line to do it.

Psychological resistance does not always close the way to do polygamy, although it is so small, that is in "certain" condition. Although the facts that polygamy is often done without completing those "certain" conditions. Therefore the polygamy law is still as the pure explanation. In another word, psychological resistance to polygamy is for the practice only which is not completing the "certain" condition anymore.

Based on the result of the research tells that this research has added the data that there is not only the practice of unhealthy polygamy -based on the data from LBH-APIK and the factors that cause divorce stated by the religious courts- that can make the divorce happen, but the husband's wish to do polygamy can also make it happen.

${ }^{37} \mathrm{LBH}$ APIK Jakarta, “Poligami sebagai Bentuk Kekerasan yang Paling Nyata atas Harkat dan Martabat Perempuan sebagai Manusia di dalam Hukum, Sosial Budaya dan Agama" available at http://www.lbh-apik.or.id/sm-pers-poligami.htm. (Cited 25 May 2009), 1. 


\section{Closing}

Actually the responsibility of a husband to give nafkah has been a boomerang or the causes of conflict happened in the husband and wife livelihoods. Then, the conflicts often be the reasons of the divorce. The bigger workload of Tuban's woman is a real implication to get the authority of a man. Tuban's woman with her exploitation attitude is only to look for the need that they think very important. In contrast, the man is unconsciously received the concept of ngawulo or ndherek morotuwo. If the woman takes a part as the holder of the responsibility- as a compensation to the power she has- becoming the one who is responsible for the family living cost, so the woman should take over the role of a husband as "the one who must responsible for the family living cost" which is actually attached to a husband/man or she must not ask the man/husband for the living cost anymore. If it is not so, the form of the woman's power changed into a form of oppression.

In this context, there is unfair treatment of men to women in the case of mantu dherek morotuwo tradition made them to do the woman's rules, without decreasing their dignity, which is still the holder of the status of the one who is the sole family breadwinner. In this condition, men has been suffered from the bigger workload, which is not only taking care of the wife and the children's needs but also all the family members in the family. During these days the husband does not think that the bigger workload (as the wage earner and the one who should take care of the house and children at once) as a bigger burden of life, and even it has been said that it is the nature of woman. While based on this research, a bigger Tuban woman's workload than man is more because the matrilocal residence tradition which symbolizes the authority of Tuban woman's under the developing gendered ideology.

\section{References}

Arto, Mukti. Praktek Perkara Perdata pada Pengadilan Agama. Yogyakarta: Pustaka Pelajar, 1998.

Collins, Randall. Sociology of Marriage and the Family: Gender, Love, and Property. Chicago: Nelson-Hall Inc., 1987. 
Depag RI, Al-Qur'an dan Terjemahnya. Madinah: Mujamma' al-Malik Fahd li Tiba'at al-Mushaf al-Sharif, 1998.

Departemen Agama RI, "Angka Perceraian di Indonesia Tertinggi Dibanding Negara Islam Lain" Ikhlas Beramal, No. 46, Th. X 2007, 15.

Ermawati MS, Eli. "Adat Pernikahan Daerah Tuban Jawa Timur", available at http://one.indoskripsi.com/node/8335 .

Handayani, Christiana S. dan Novianto, Ardhian. Kuasa Wanita . Yogyakarta: LKiS, 2004.

Handayani, Yuni Sri. "Paranan Peradilan Agama dalam Menyelesaikan Cerai Gugat Berdasarkan UU No.7 Th. 1989 (Studi Kasus di PA Bandung)", available at http://digilib.upi.edu/union/index.php/record/view/4479. (Cited 1 Maret 2006).

Jauziyyah, Ibn al-Qayyim al-. Zâd al-Ma'âd . Juz 5. Bairut: Muassasah al-Risalah, 1994.

Kusujiarti, Siti. "Antara Ideologi dan Transkrip Tersembunyi: Dinamika Hubungan Gneder dalam Masyarakat Jawa" in Abdullah, Irwan. Sangkan Paran Gender. Yogyakarta: Pustaka Pelajar, 1997.

LBH APIK Jakarta, “Poligami sebagai Bentuk Kekerasan yang Paling Nyata atas Harkat dan Martabat Perempuan sebagai Manusia di dalam Hukum, Sosial Budaya dan Agama" available at http://www.lbh-apik.or.id/sm-pers-poligami.htm. (Cited 25 Mei 2009)

Lev, Daniel S. Peradilan Agama Islam di Indonesia, trans. Zaini Ahmad Noeh. Jakarta: PT. Intermasa, 1982.

Murdani, Fithriyah Wardie. "Kewajiban dan Hak Suami Isteri dalam Keluarga Islam" Al-Insan, Vol. 2 No. 3, (2006).

Nasir, Nasrullah. Teori-teori Sosiologi. Bandung: Widya Padjadjaran, 2009.

Puspitawati, Herien. “Teori Konflik Sosial dan Aplikasinya dalam Kehidupan Keluarga" in Bahan Ajar ke-3: Mata Kuliah Pengantar Ilmu Keluarga, available at http://iirc.ipb.ac.id/jspui/bitstream/123456789/40379/2/teo ri\%20konflik\%20sosial\%20dan\%20aplikasi \%20dalam\%20kehid upan\%20keluarga.pdf. (Cited 10 Oktober 2010) 
Ritzer, George dan Goodman, Douglas J. Teori Sosiologi Modern, trans. Alimandan. Jakarta: Kencana Prenada Media Group, 2010.

al-Syâfi'î. al-Umm. Cet. 1. Juv IV. Bairut: Dâr al-Kutub al-'Ilmiyah, 1993.

Suma, Muhammad Amin. Hukum Keluarga Islam di Dunia Islam. Jakarta: PT. Raja Grafindo Persada, 2004.

Tim. Masyrû' Qanûn al-Ahwâl al-Shakhsiyyah al-Muwahhad li al-Iqlimain al-Mishr wa al-Suriy. Bairut: al-Dar al-Shamiyyah, 1996.

Zuhaylî, Wahbah al-. Al-Figh al-Islâmî wa Adillatuh.VII. Suriya: Dar alFikr, 1989 